\title{
ECO-CITIES: THE MAINSTREAMING OF URBAN SUSTAINABILITY - KEY CHARACTERISTICS AND DRIVING FACTORS
}

\author{
S. JOSS \\ University of Westminster, United Kingdom.
}

\begin{abstract}
Efforts to innovate in urban sustainability have in recent decades culminated in a new phenomenon: eco-cities. In recognition of the key role played by cites both as the cause of, and potential solution to, global climate change and rapid urbanisation, the concept and practice of eco-cities have since the early 2000s gained global significance and become increasingly mainstream in policy-making. This study provides an analysis of contemporary eco-city developments by systematically mapping some 79 recent initiatives at global level; evaluating key characteristics (including development type, phase and implementation mode) and discussing the factors (such as technological development, cultural branding, and political leadership) that drive and condition innovation in this area. The article concludes by outlining a research agenda for addressing both the challenges and opportunities of future eco-city governance.
\end{abstract}

Keywords: eco-city, eco-town, governance, socio-technological innovation, urban sustainability.

\section{INTRODUCTION}

Since the early 2000s, a new wave of so-called 'eco-city' initiatives has swept across the world [1]. Destiny Florida in the USA, Tangshan Caofeidian in China, Gwang Gyo in South Korea and Masdar in the United Arab Emirates are among a string of major new developments that have attracted international attention as the (self-proclaimed) next generation of low-carbon and low-waste cities. In addition, many existing cities have embarked on concerted urban sustainability action programmes and similarly adopted the eco-city label to promote their efforts. This prompts the questions of how one meaningfully defines eco-cities given the apparent global spread and variety of forms - in other words, what are their defining features, and how are they distinct from 'normal' cities? - and what their significance is in terms of contemporary urban sustainability policy - that is, what gives impulse to their development, and what relevance do they have?

This article aims to address these questions by, firstly, analysing key characteristics of eco-cities, based on a systematic survey of 79 eco-city initiatives carried out in 2009-2010. In doing so, this study fills a gap, as to date only few systematic global surveys have been carried out (for an early survey, albeit with focus on smaller 'eco-neighbourhoods', see Barton [2]; for a recent in-depth discussion of a selection of eco-city initiatives, see Downton [3]). Second, the article discusses the factors that together drive eco-city innovation and, thus, explain its significance. In turn, this helps to identify, for future research, issues that are critical concerning the governance of eco-city development and innovation.

\section{HISTORICAL, CONCEPTUAL AND METHODOLOGICAL PERSPECTIVES}

Before turning to the analysis of the 79 identified eco-city initiatives, it is worth briefly tracing the roots of the eco-city phenomenon, and outlining underlying conceptual perspectives. This is followed by a discussion of the methodological approach used in this study.

\subsection{Historical developments}

As has been well documented, efforts to render cities environmentally and socially sustainable are not new. Urban planning and regeneration over the last 100 years or so have been significantly 
influenced by attempts to redress the perceived detrimental effects of large-scale urbanisation, such as environmental degradation, social inequalities and urban sprawl. The Garden City, New Town and Techno-City are nineteenth and twentieth century exemplars of such attempts to reinvent the city in the (post)industrial era (see, for example, Kargon and Molella [4]). While these earlier concepts and models have undoubtedly had a bearing on the current eco-city development, the latter has its own distinctive characteristics and history, reflecting the rise in environmental and urban policy and politics over the last 40 years or so and, in particular, the politics of global sustainability and climate change since the 1990s. Three phases of eco-city development can be distinguished.

Phase I: 1980 s to early 1990s; grassroots movement/visions. The term 'eco-city' itself can be traced back to the 1980s, when it was first coined in the context of the rising environmental movement, notably by Richard Register through his Urban Ecology initiative and the publication of Ecocity Berkeley [5]. In 1990, this led to the first in a series of international eco-city conferences. Throughout the 1980s and early 1990s, 'eco-city' remained mainly a normatively prescriptive concept, 'a collection of...ideas about urban planning, transportation, health, housing, economic development, natural habitats, public participation and social justice...' according to Roseland [6], with practical examples relatively few and far between. As Barton ([2], chapter 5) noted, there was initially a considerable gulf between aspiration and actual achievement resulting from various economic, political and behavioural constraints inhibiting the realisation of eco-city developments.

Phase II: 1992 to early 2000s; local and national experimentation. The United Nations 'Earth Summit' (Rio de Janeiro, 1992) and the resulting sustainable development programme ('Agenda 21 ') formed the background against which eco-city concepts were increasingly translated into practice. As part of this second phase, for example, Curitiba (Brazil) was heralded as an early model eco-city on account of its advanced, integrated public transport system initiated in the early 1980s [7]. Waitakere (New Zealand) became known for its attempt to integrate Western and Maori concepts of sustainable resource management in its eco-city master plan [8]. Schwabach, a small German city, was selected by the federal government for a pilot study to design a model for urban sustainability development to be emulated elsewhere in Germany, while in Sweden, all local authorities were required to implement Agenda 21 plans to encourage environmental sustainability [9].

Phase III: 2000s to present; global expansion/policy mainstreaming. The current, third phase and focus of this study - began to manifest itself in the early to mid 2000s through the concurrent globalisation (in terms of geographic spread and international profile) and mainstreaming (in terms of policy uptake and practical implementation) of the eco-city phenomenon. Thus, eco-city initiatives are dotted in growing numbers around the globe; and several high profile policy initiatives at national and international levels have begun to promote eco-city innovation, such as the Clinton Climate Initiative (a collaborative project between the Clinton Foundation and the C40 Cities Climate Leadership Group), the European Commission's Eco-City Project, and the World Economic Forum's SlimCity knowledge exchange initiative [10].

\subsection{Conceptual perspectives}

As can be expected from the historical trajectory of eco-city developments, the term 'eco-city' and its use across time and settings are conceptually fluid. Mirroring the above three phases, one can identify three conceptual perspectives: firstly, what may be called the 'normative' perspective, which is informed by conceptually, ideologically and politically driven, normatively prescriptive ideas and demands. As Roseland [6] notes, these present a collection of more or less disconnected strands of 
thinking and activism based on an array of theories and concepts, including social ecology, community economic development, the green movement, bio-regionalism, technology studies and sustainable development, making it difficult to arrive at a single accepted definition. This perspective is mainly associated with the first phase of development, and the term eco-city here serves as a conceptual framework to bring together and assemble a diversity of visions, concepts and activities with the overarching aim of proposing mainly grassroots-based alternatives to urban development, politics and life.

The second, 'regulatory' perspective coincides with the second phase of eco-city development. Here, the concept of eco-city becomes increasingly standardised by, and in turn takes on a standardising role within, the policy framework of sustainability. This is mainly due to the international adoption of the sustainability agenda following the Brundtland report (Our Common Future, 1987) and the 1992 Rio Earth Summit, and its subsequent implementation at (sub)national levels through Agenda 21. Schwabach (see above) and Hamm (see below) are examples of this regulating process of defining standards through initial piloting and subsequent use as models to incentivise and guide eco-city development more widely.

The third - mainly associated with the current phase of development - may be described as the 'innovation' perspective in that the term 'eco-city' becomes more centrally infused with conceptual notions of innovation, that is, the perceived opportunity to stimulate socio-technological innovation, business development and cultural branding. The focus of this perspective, as the analysis below shows, is overwhelmingly related to current preoccupations with 'decarbonising' the world's economies and reducing the carbon footprint of cities, given that cities are key contributors to greenhouse gas emission. Hence, the eco-city concept becomes further standardised, as reflected in many of the initiatives reported here, where there is an explicit focus on - often very specifically defined and labelled $-\mathrm{CO}_{2}$ reduction measures.

Importantly, while to an extent a positive correlation exists between the historical phases and the conceptual perspectives, this is not to say that, for example in the current phase, only the innovation perspective is present. The first and second perspectives, too, are in play, albeit in less dominant form. This is apparent in cases (see below), such as Auroville (India), EcoVillage, Ithaca (USA) as well as in the recent Transition Town Movement (see Barry and Quilley [11]) - where the first perspective is to the fore - and in many of the retro-fit initiatives that have evolved from the second perspective.

This conceptual diversity - matched by a plurality of practical eco-city initiatives - makes the task of defining eco-cities difficult, unless one opts for either very loose definitions, see for example, the definition by Ecocity Builders [12] according to which 'an ecocity is a human settlement that enables its residents to live a good quality of life while using minimal natural resources' - or narrow definitions - see, for example, the UK government's definition, according to which 'eco-towns must be new settlements, separate and distinct from existing towns...' (Department for Communities and Local Government [13]), neither of which is analytically particularly helpful. Therefore, eco-cities are defined here in relation to a set of analytical categories, as outlined in the next section. This should then help to demarcate eco-cities - following Barton's earlier analytical framework for 'eco-neighbourhoods' [2] - from 'normal' cities in terms of scale and policy significance, as discussed further below.

\subsection{Methodological approach}

The basis for the present study was a 'horizon-scanning' exercise aimed, firstly, at determining the scale and extent of the phenomenon and capturing the diversity of projects. This was done by 
identifying contemporary (either self-referred or externally attributed) eco-city initiatives through the analysis of the relevant academic literature, conference proceedings, policy documents, and websites of international networks and interest groups (the latter including Eco-Cities, Ecocity Builders, Ecocity World Summit, Sustainable Cities [12, 14]). The key terms/descriptors used were 'eco-city' and 'eco-town'. The search results were triangulated through cross-referencing of information/sources. Given the focus on the recent period, earlier initiatives which did not go beyond conceptual stage (e.g. Halifax, Australia) were not included.

While this methodology may not capture all eco-city developments (especially non-English ones, or local ones without international outreach), it should be sufficiently comprehensive and robust to identify all major initiatives reported internationally. Nevertheless, it is important to note that some cities with impressive track records in urban sustainability innovation may not be captured here because they have not overtly adopted the eco-city discourse/label. Zurich (Switzerland) is arguably a case in point: it frequently features in the top range of 'most liveable'/'green' cities in international surveys (such as the Mercer's Quality of Living survey). However, because sustainability is a key principle enshrined in the Swiss constitution, the city is used in dealing with urban sustainability as a matter of course in its planning and day-to-day business.

The second step of research entailed a detailed profiling of each identified eco-city initiative, including information about the nature of development, key actors involved and data availability. The full results of this part of the research are published separately [15]. All information pertaining to individual eco-city initiatives discussed in the following sections is distilled from this source. See also images at $[10,14]$ and www.westminster.ac.uk/ecocities.

The third step involved the identification of key trends and patterns across the identified eco-cities (see Table 1). To this end, a typology was developed including the following analytical categories and variables: (i) type of eco-city development (new development; expansion of urban area; 'retro-fit' development); (ii) development phase (pilot/planning stage; under construction; implemented); and (iii) key implementation focus/mode (technological innovation; sustainability visions; civic empowerment). Furthermore, a transversal analysis was carried out with focus on various external factors driving and conditioning eco-city developments, including: (iv) environmental issues; (v) socio-economic pressures; (vi) business development; (vii) cultural branding; (viii) political leadership; and (ix) international co-operation.

Table 1: Analytical categories for profiling and comparing eco-city initiatives.

\begin{tabular}{lll}
\hline & Eco-city characteristics & \multicolumn{1}{c}{ Driving factors } \\
\hline Type of development & I - new development & Environmental challenges \\
& II - expansion of urban area & Socio-economic pressures \\
& III - retro-fit development & Business development \\
Development phase & 1 - pilot/planning phase & Cultural branding \\
& 2 - under construction & Political leadership \\
Key implementation & 3 - implemented & International co-operation \\
mode & a - technological innovation & \\
& $\mathrm{b}-$ integrated sustainability plan & \\
\hline
\end{tabular}




\section{ECO-CITY TYPES AND CHARACTERISTICS}

Using the above methodology, 79 eco-city initiatives were identified. As Table 2 shows, these are spread globally. A majority are located in Europe (34), with Scandinavian countries, the United Kingdom and Germany heading the table. The second largest concentration is found in Asia/Australasia (27), followed by North America (9), Africa (4), Latin America (3) and the Middle East (2). In at least three countries, there are governmental initiatives under way involving a series of eco-cities: in England, the new eco-town projects of North-West Bicester, Rackheath, St Austell, and Whitehill-Bordon; in India, the cities of Kottayam, Puri, Thanjavur, Tirupati, Ujjain, and Vrindavan; in Japan, the cities of Yokohama, Kitakyushu, Minamata, Obhirio, Shimokawes and Toyama.

The findings demonstrate the extent to which eco-cities have in recent years become a global phenomenon, not limited, as might have been assumed, to developed countries in the Western hemisphere. Innovative eco-city initiatives are as likely to be found in China, Kenya, Japan, South Korea and South Africa, as in Canada, Germany, Great Britain, Sweden and the United States. Some of the most original eco-city projects are currently being planned or under construction in the Middle East and East Asia. The findings also show quite how far eco-cities have moved on since the 1970s to 1990s: from a relatively loosely defined concept with only a few, mainly experimental pilots, to a multitude of concrete, practice-led initiatives.

Using the aforementioned three categories of eco-city characteristics, the surveyed eco-cities were analysed with a view to identifying possible patterns or trends (see Table 3 ). The first relates to the type of development, whereby a distinction is made between: (I) new development - that is, a city built from scratch; (II) expansion of existing urban area - for example, a new district or neighbourhood; and (III) 'retro-fit' development - that is, sustainable development innovation/ adaptation within existing urban infrastructure.

While in the media the most high-profile eco-city projects may be type I, especially new cities built at large scale and through international consortia, such as Tangshan Caofeidian (with engineering/design firm Sweco), Gwang Gyo (with Dutch architects MVRDV) and Masdar (with Foster \& Partners and Massachusetts Institute of Technology, MIT), this analysis demonstrates that these represent just under one quarter of the surveyed cities, with type II making up over one quarter and type III close to one half. In other words, significant eco-city innovation takes place through the expansion of existing urban areas, such as Treasure Island (USA; regeneration of former military airbase to provide 8000 mixed-use buildings and green spaces) and Greenwich Millennium Village (UK; redevelopment of Europe's largest former gas works with plans for 3000 residential units and ecology park), as well as through the 'retro-fitting' of existing housing stock, transport infrastructure, energy systems and waste management systems, such as Rizhao, China's acclaimed 'Garden City' (shift to renewable energy and 'greening' of inner city) and Trondheim in Norway (European Commission-funded model eco-city, with focus on energy-efficient buildings and waste-to-energy systems). These different types prompt varied approaches to eco-city innovation, for example, working with existing building stock - including the preservation of historic and cultural sites - in retro-fit cases requires different technological and planning solutions than in the case of new builds or urban expansion.

The second analytical category relates the development phase, thus distinguishing between whether an eco-city project is: (1) at planning stage; (2) under construction or (3) implemented. It should be noted that while 'implemented' in this context means that the original eco-city plan has been achieved, it does not necessarily mean static: further innovation may well take place on a continuous basis. Approximately one quarter of initiatives were at planning stage at the time of the survey, whereas just under one half were under construction, with more than one quarter having been implemented. This is a further indication of the rapid expansion of the eco-city phenomenon since the mid 2000s. 


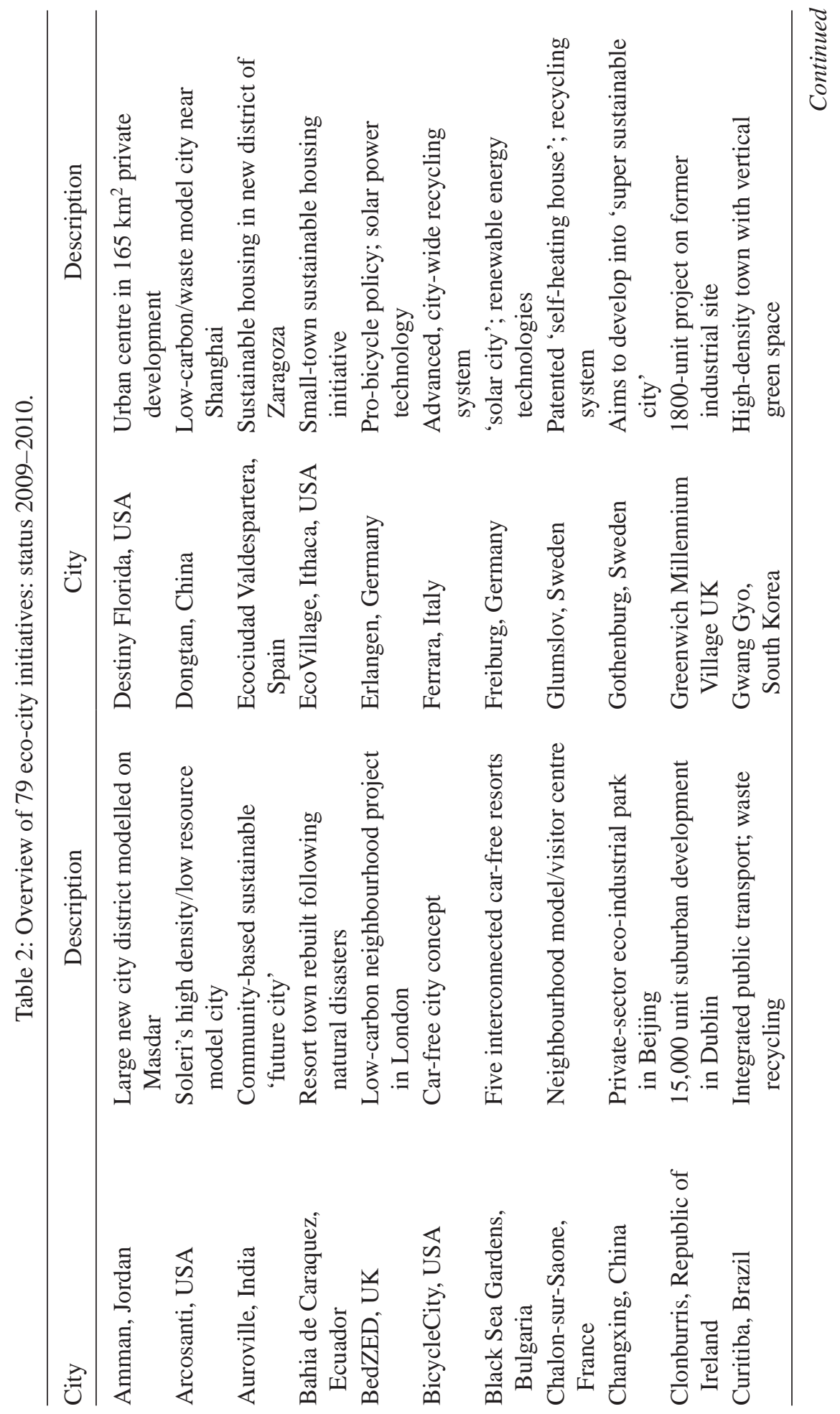




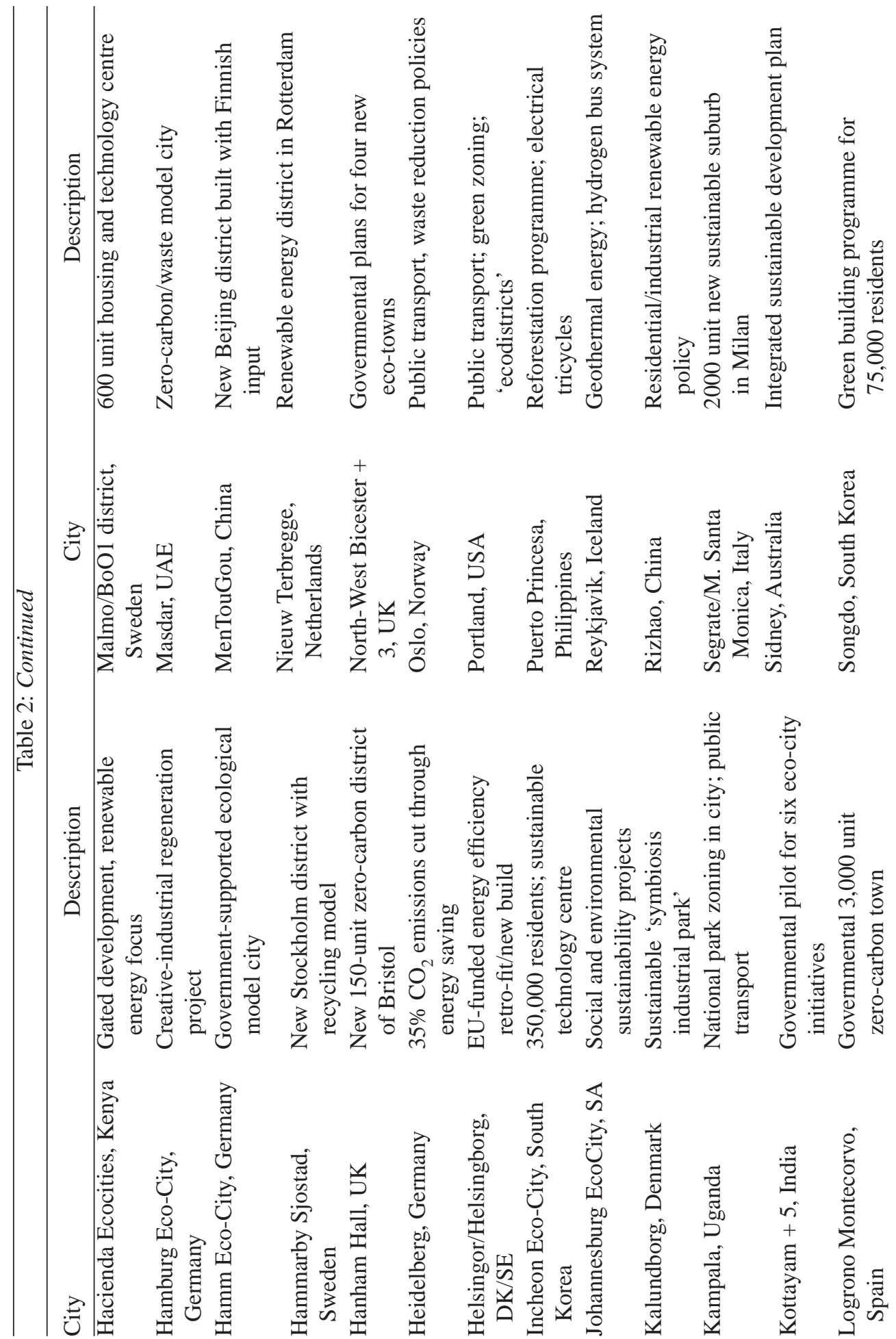




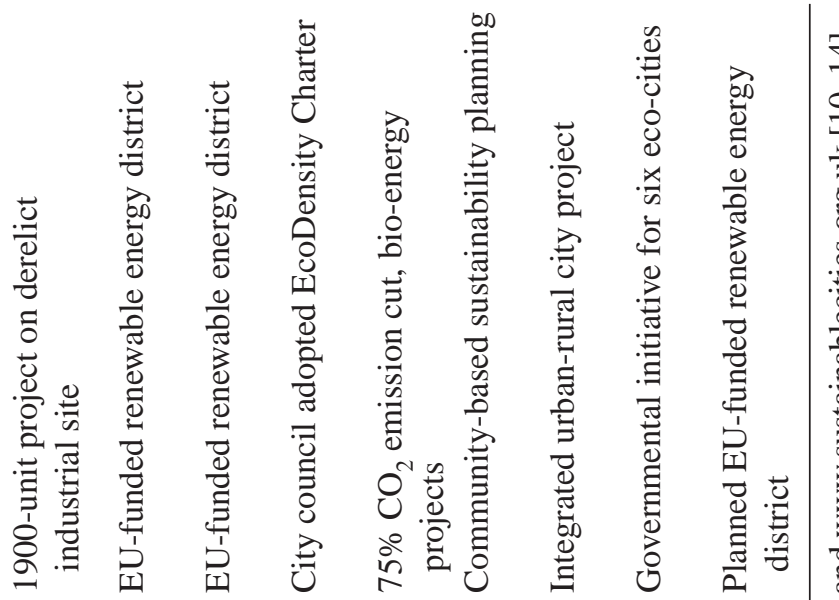

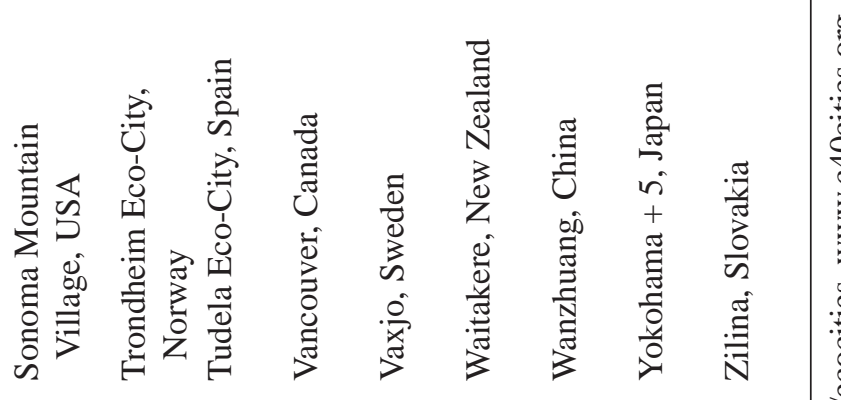

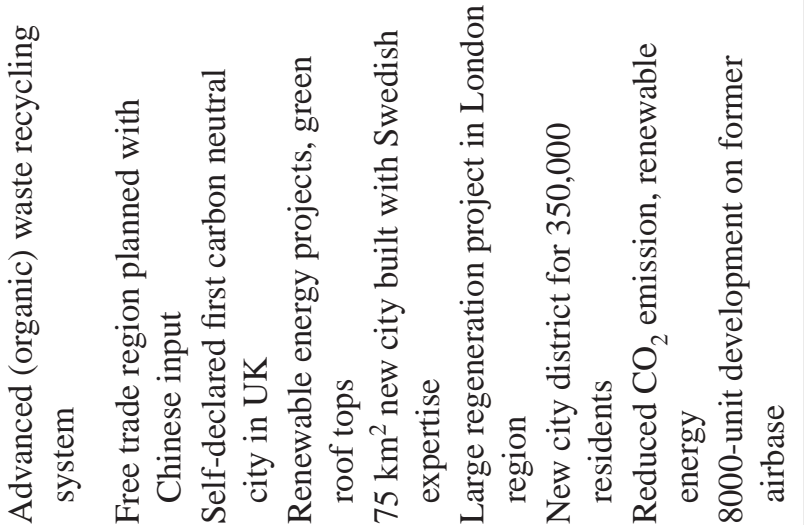

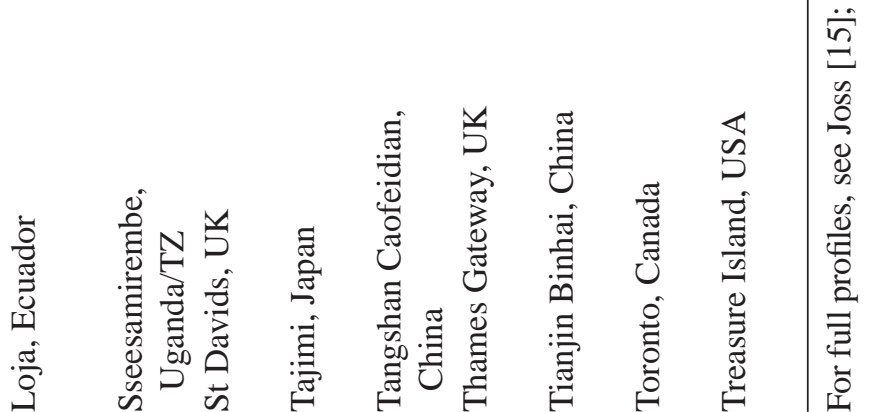




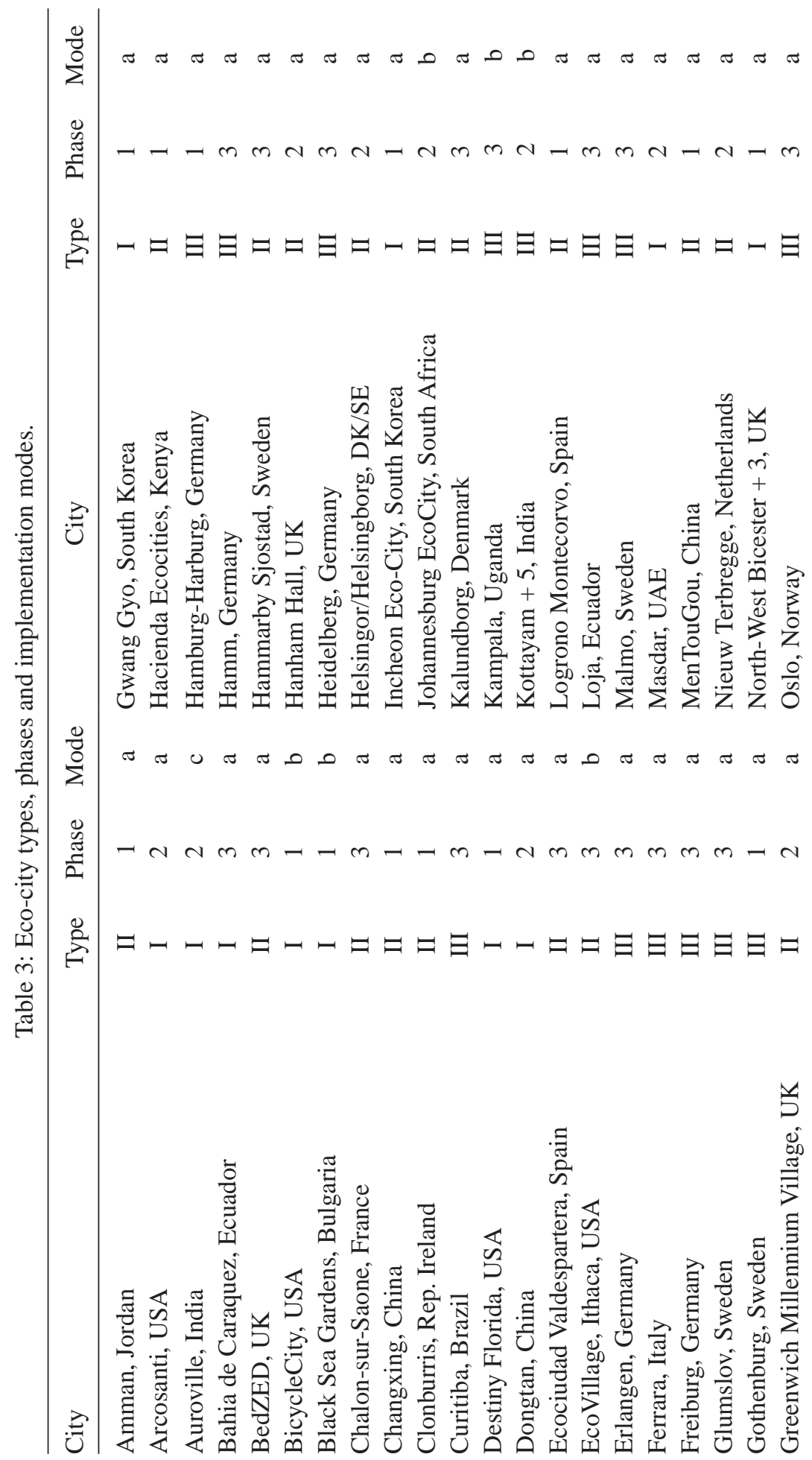




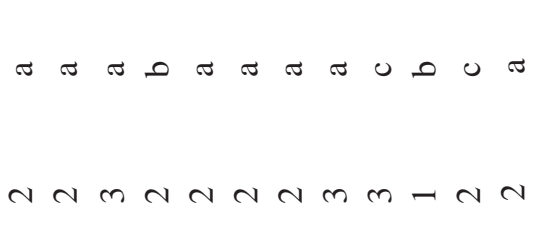

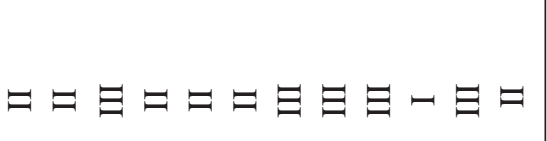

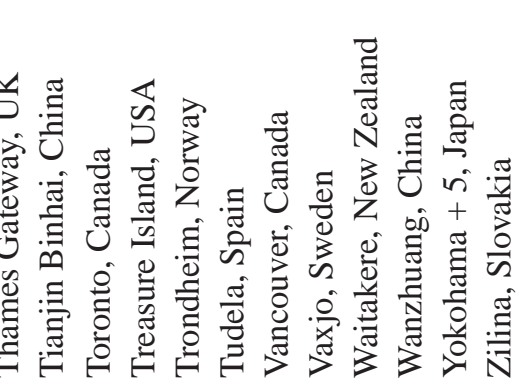

$$
\begin{aligned}
& \pi, \pi \pi 5 \pi, 0500 \pi
\end{aligned}
$$

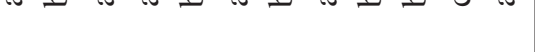

$$
\begin{aligned}
& m m m n-a n n m a n
\end{aligned}
$$

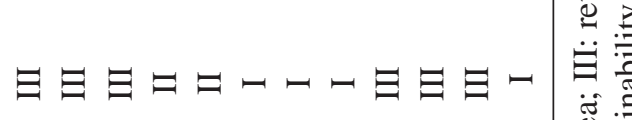

$$
\begin{aligned}
& \text { تृ் } \\
& \frac{\stackrel{0}{0}}{2} \\
& \ddot{\sim}
\end{aligned}
$$


It also reinforces the aforementioned point about important eco-city innovation taking place in existing cities either through expansion or 'retro-fitting', where developments are typically more advanced than in the case of new builds. Among the retro-fit examples, only two are presently at planning stage following their announcement in the second half of 2009 - the 'Eco-City Hamburg-Harburg' project to regenerate the city's old harbour, and the 'Gothenburg Super Sustainable City' plan based on the city's 2050 sustainable futures project - while all others are either under construction or have been implemented. Freiburg (Germany) and Vaxjo (Sweden) have earned a reputation as among Europe's 'greenest' cities for their concerted urban sustainability efforts.

The third category relates to the implementation focus - that is, the key modes by which eco-city plans are (to be) realised. This includes: (a) technological innovation; (b) integrated sustainability planning and (c) civic empowerment/involvement. This categorisation should not be understood rigidly, as typically an eco-city development can be expected to combine two or more of these implementation modes (which may sometimes be in tension or competition with one another). It is, nevertheless, useful for pinpointing key features of eco-city development and the key actors involved, reflecting both international trends and local specificities.

Some three quarters of the identified initiatives emphasise technological innovation as the means of achieving eco-city development. Of these, a large majority focuses on energy technologies, including renewable energy. Freiburg, for example, has become known as Germany's 'solar city'; Sseesamirembe (Uganda) and Logrono Montecorvo (Spain) centre upon hybrid solar-wind power. A smaller proportion of 'technological innovation' cases focus (in descending order) on waste management (waste-to-energy), transport infrastructure and water management. The latter is particularly pronounced in the case of the Indian governmental eco-city initiatives. Just under one quarter of the cases take a more 'holistic' sustainability approach (b) as a way of realising eco-city development, by emphasising the integration of technological, social and cultural aspects. Sydney (Australia) and St Davids (Wales) are examples of this category; the former with its Sustainable Sidney 2030 Vision master plan, implementation of which began in 2008; the latter emphasising the connection between technological innovation, behavioural change and education driven by local community involvement. The remaining few cases focus on civic empowerment and community involvement (c): Tajimi (Japan), winner of the 2003 'Top Eco-City Contest of Japan', represents more of a 'top-down' approach in that the city authorities have take a lead in involving citizens and stakeholders in hearings with policy-makers concerning the implementation of the city's environment plan. By contrast, Auroville with its community-based initiatives represents a distinctly more 'bottom-up' approach.

The strong technology focus in a majority of cases can be explained by the mainstreaming of eco-cities in recent years. This may arguably have led to the dilution of the original ideas and concepts (with emphasis on social justice, civic empowerment and local democracy), which do not appear to feature as largely in many current projects, and the prevalence of mainly technocratic approaches reflecting current climate change and urbanisation policy frameworks.

Considering these features, the question arises as to how coherent a phenomenon are the diverse eco-city initiatives. The evidence suggests that it would be missing the point to define eco-cities narrowly. For example, it would be misleading to use the term exclusively for new developments (type I), given the significant initiatives occurring within existing cities (type II/III). Likewise, it would be too limiting to confine the term to particular conceptual approaches and forms of implementation, given the rich diversity found. As the phenomenon expands, eco-cities can be expected to diversify further, reflecting the various specific contexts of application.

However, it should still be useful, not least for the purposes of analysing the current phenomenon, to identify some key criteria as a way of demarcating eco-cities. Here, the following three related 
criteria are suggested: (i) scale - an eco-city refers to an urban sustainability development of substantial scale in terms of the area, infrastructure and innovation concerned; (ii) sectors development typically takes place across several sectors (housing, transport, energy, waste, water, land, etc.); (iii) policy - it is a development that is formulated as, embedded in, and supported by, policy processes. According to these criteria, small developments - such as single sustainable housing or waste plant projects (however important in themselves), or a mere publicity/branding exercise without substantive underpinning - are excluded from this definition on account of their lacking the scale and significance that require concerted, cross-sector application and policy commitment.

The purpose of trying to define eco-cities in such a way, then, serves not to impose a narrow concept or view on this evolving phenomenon, but rather to focus on its key analytical dimensions, to map its contours based on an understanding of the overlapping and shifting boundaries between eco-city initiatives and 'normal' cities, and to facilitate critical inquiry into opportunities for and challenges to eco-city innovation.

\section{DRIVING FACTORS}

Another question is what is the significance of the emerging eco-city phenomenon. How are we to understand the apparently fast growing interest in, and demands for, eco-cities? Detailed answers can be expected to be found in the analysis and comparison of individual cases (a subject for additional research) pointing to specific causes and contexts. Generally, the combination of the following six factors appears to be driving the phenomenon: environmental challenges, socioeconomic pressures, business development, cultural branding, political leadership, and international co-operation. While the first and second factors seem particularly key, many of the cases featured in this study demonstrate that the other four factors are similarly important in bringing about and conditioning eco-city innovation.

\subsection{Environmental challenges}

By name/definition, eco-city developments respond to existing and anticipated environmental challenges by seeking to mitigate, and adapt to, environmental threats through a mixture of infrastructure (housing, transport, etc.) and process (waste management, energy consumption, etc.) design and innovation. In some cases, this comes in response to specific local environmental challenges, such as tackling water/river pollution (e.g. Kottayam) and reversing deforestation (e.g. Loja/Ecuador; Obihiro/Japan; Puerto Princesa/Philippines), thus taking on particular local characteristics. In most cases, however, the response is in relation to more general environmental pressures affecting urban areas, such as air pollution and waste-related problems. The reduction of $\mathrm{CO}_{2}$ and other greenhouse gas emissions runs as a common thread through most initiatives. This is not surprising, given the growing international recognition of the threat of global climate change and the related need to shift towards a low-carbon economy, with cities currently estimated to account for approximately two-thirds of global energy use and $70 \%$ of global $\mathrm{CO}_{2}$ emissions (e.g. Clinton Climate Initiative [10]). Several cases have explicit $\mathrm{CO}_{2}$ reduction targets as their key aim and focus: for example, Freiburg claims to have achieved a $25 \% \mathrm{CO}_{2}$ reduction by 2010 (compared with 1992 levels) and aims to go further still. Similarly, Heidelberg (Germany) has achieved a $\mathrm{CO}_{2}$ reduction of $30 \%$ by the early 2000s; Toronto (Canada) $40 \%$ by 2009; and Destiny Florida has signed up to a target of $80 \%$ reduction by 2050 (compared with 1990 levels of a similarly sized US city). Some go even further by claiming carbon-neutral footprints, such as Logrono Montecorvo; Masdar, 'the world's first fully carbon-neutral city'; Malmo (Sweden), aiming to be carbon-neutral by 2020; and Black Sea Gardens (Bulgaria), 'the world's first carbon-neutral luxury resort'. 


\subsection{Socio-economic pressures}

The second key factor driving eco-city innovation is socio-economic. In 2008, for the first time in human history, over $50 \%$ of the global population lived in cities. This is expected to rise to $60 \%$ by 2030 [16]. Thus, rapid urbanisation creates pressure to grow existing, as well as build new, cities. This is particularly so in developing countries, including in Africa (which at present has the highest rate of urbanisation), China and India. Some of the most innovative eco-city developments currently take place in these parts of the world: China, for example, is reported [17] to have embarked on an ambitious programme to build some 40 new eco-cities (see also Table 1: Changxing, Dongtan, MenTouGou, Tangshan Caofeidian, Tianjin Binhai, Wanzhuang); South Korea has embarked on three major projects (Gwang Gyo, Incheon, Songdo); in both Japan and India a series of existing cities (see above) have been selected by government to serve as models for eco-city innovation and, in the case of India, to provide training for civil servants from other cities. In 2010, India also signed an agreement with Japan to build a series of new eco-cities in the Delhi-Mumbai corridor [18]; and several small (Johannesburg EcoCity/South Africa), medium-sized (Hacienda Ecocities/Kenya) and large (Kampala/Uganda; Sseesamirembe) initiatives are under way across Africa. In the Middle East, Amman (Jordan) has responded to the demand for additional housing for one million residents by commencing work in 2010 on a new eco-district modelled on Masdar.

However, it is not just in developing countries where increasing urbanisation has been the impetus for eco-city development. For example, the UK government's plans (launched in 2008 by the housing division of the Department for Communities and Local Government [13]) for a series of new 'eco-towns' (North-West Bicester, Rackheath, St Austell, Whitehill-Bordon) across England, and the plans for the regeneration of the Thames Gateway, appear principally driven by the need to increase the housing stock due to a significant shortfall of available housing particularly in the South and South-East of England. Destiny Florida is a response to current projections showing a doubling of Florida's population by 2050 accompanied by significant urban sprawl. Its design aims to avoid the latter by adopting the principle of '4Cs' (conservation, countryside, centres and corridors) for the 64 square mile area. In similar vein, the plans unveiled in 2009 to transform Gothenburg (Sweden) into a 'super sustainable city' were prompted by predictions of population growth (by 8000 inhabitants per year by 2020).

In existing urban centres, a further, related factor is the aim to revitalise urban centres socioeconomically by shifting away from old industries to new knowledge-based, green technology and creative industries, as illustrated by Hamburg-Harburg (Germany), Kalundborg (Denmark), Malmo, and MenTouGou.

\subsection{Business development}

The necessity to design and develop urban areas more sustainably both in response to environmental and socio-economic challenges opens up opportunities for technological innovation and business development. Both research organisations and businesses (engineering firms, architecture practices, investment banks) have become involved, often in partnership, in current eco-city developments, thus contributing to their mainstreaming. Several cases are private-sector initiatives, such as, Black Sea Gardens (developed by a group of property companies), Changxing (Vanion Group/Arup), Destiny Florida (Pugliese Development Corporation), Segrate/Milano Santa Monica (Italy; Vegagest private bank), Songdo (New Songdo International City Development), and Sonoma Mountain Village (USA; Codding Enterprise). Others being developed through public-private partnerships include: Gwang Gyo (municipality/Daewoo Consortium), Hanham Hall (UK; municipality/Barratt 
house builders), MenTouGou (government/VTT Finnish technical research organisation), Treasure Island (municipality/Lennar/Wilson Meany Sullivan), and Wanzhuang (government/SIIC).

Eco-city business development is closely aligned with the promotion of, and support for, technological innovation (including 'green' technologies). For example, one of the goals of Changxing Ecological City is to create a new science/industrial park. Kalundborg pioneered the concept of the 'symbiosis industrial park' aimed at co-locating businesses in such a way as to share resources and, thus, increase resource efficiency. Masdar aims to become the 'silicon valley for green energy', as part of which is has set up the Masdar Institute of Science and Technology in collaboration with MIT (Cambridge, USA). The Thames Gateway Institute for Sustainability [19], a consortium of private companies, universities and local/regional authorities launched in early 2010, plans to use the Thames Gateway, Europe's largest regeneration programme, as a test bed for developing new technological applications.

\subsection{Cultural branding}

A further factor driving the eco-city phenomenon is the opportunity for the (re-) branding of a city, and in particular the cultural branding of urban sustainability. While this may only be a secondary factor, it can nevertheless be instrumental in shaping individual eco-city initiatives. In the first instance, the label 'eco-city' is used to denote the particular environmental credentials of a city and so to mark it out as innovative and competitive. Thus, for example, since 2000 Japanese cities have competed for the top spot in the national eco-city contest; in the USA a list of top sustainable cities is published annually (with Portland, Oregon, and San Francisco currently occupying the top spots). Masdar is a prime example of an initiative driven by the ambition to become 'the world's first carbon-neutral, zero-waste city'. In Germany, both Freiburg and Hamm have been known as 'ecological capital' (the latter winning a same-named national award in 1998), while Hamburg has more recently joined the competition by styling its regeneration project as Germany's first 'entirely sustainable creative-industrial corporate development'. Vaxjo and Freiburg both frequently trade on the label as Europe's 'greenest city'. Malmo promotes itself variably as climate/solar/eco-city, while Gothenburg aims to become a 'super-sustainable city'. Hanham Hall refers to itself as England's first zero-carbon development, competing with St Davids, which claims to be the UK's first carbonneutral city.

Some eco-city initiatives also use eco-city branding through educational and cultural activities, such as 'hands-on' demonstration sites/objects (for example, Vaxjo), visitor centres and museums (Chalon-sur-Saone/France; St Davids). In addition, in some cases - such as Black Sea Gardens, Destiny Florida (America's first eco-sustainable city), and Hacienda Ecocities - the eco-city label is used to denote more upmarket developments, where advanced environmental standards (clean water, safe transport, green spaces) are promoted as indicators of a safer, more prosperous way of urban living (mainly for private residents). Again other initiatives - for example, Auroville, EcoVillage at Ithaca and Changxing - emphasise the combination of a socially harmonious and environmentally sustainable way of living. Furthermore, some developments promote eco-city as a cultural experience, including Rizhao (city of sunshine) and Songdo (including themed parks/districts).

\subsection{Political leadership}

Translating an eco-city vision into a tangible plan and following this through to implementation requires political coordination and leadership. What form this takes depends on the particular governance system in place. In several cases, eco-city developments have been signature projects of 
mayors: for example, starting in the 1970s Jaime Lerner spearheaded the transformation of Curitiba into one of the earliest, internationally acclaimed eco-city initiatives. Upon his election as mayor of Loja in 1996, Jose Castillo embarked on a concerted programme of urban 'eco-transformation' relating to transport, housing, waste management and green spaces. Following his appointment in 2001 as mayor of Rizhao, Li Zhaoqian began to roll out solar power technology across the city, with a large majority of houses having since been retro-fitted with solar water heating and photovoltaic electricity generating systems, and all street and public lighting running on solar power.

In other cases, it is elected city councils or regional governments that initiate eco-city developments by, for example, passing resolutions or legal acts, adopting master plans, and setting up dedicated offices and programmes. Among these are Changxing (2005 master plan by the Beijing authorities), Freiburg (1986 master plan; 1996 Climate Protection Protocol), Kampala (various urban sustainability acts since early 2000s), Oslo (2001 Earth Charter), Sydney (1993/1999 local government acts), and Vancouver (Canada; 2008 EcoDensity Charter, 2010 Greenest City Initiative). Sometimes decisions are made in consultation with the electorate/residents, such as in Portland (for example, ballot on metropolitan greenspaces programme), Sydney (where the city established an 'environmental partnership' with civil society groups), and Tajimi (see above).

Again in other cases, eco-city initiatives have been championed by national governments. For example, the Chinese government has been instrumental in driving forward the new wave of eco-city developments as part of its economic and urban growth strategy, including Tianjin Binhai, Dongtan, MenTouGou and Tangshan Caofeidian. Similarly, the government of the United Arab Emirates has been the driving force behind Masdar; the Ugandan government in 2006 launched Sseesamirembe Eco-City as a major low-carbon development area (covering some 200 square miles); and the Icelandic government is focusing on its capital Reykjavik (where half of the country's population lives) in its drive to turn the country's energy consumption fully fossil-free by 2050 . The Indian (2001, 2010), Japanese (2009) and United Kingdom (2009) governments each selected a series of cities (existing sites in the case of Japan, new sites in England, and both existing and new ones in India) to drive eco-city innovation.

\subsection{International co-operation}

Throughout its past and present phases, eco-city development has been significantly influenced by international co-operation (see section 2.1). While in its early, pioneering stage, international networking mainly took place among academics and activists (through international eco-city conference series and the Eco-Cites and Ecocity Builders networks, among others), in its current phase this has spread to urban/technology developers and political actors. This is arguably not surprising given the global nature of the aforementioned key environmental and socio-economic drivers. What is significant is the degree of active international co-operation found at individual level through knowledge transfer and joint business development. For example, Bioregional, the UK sustainability business behind BedZed (London) is currently closely involved in the development Johannesburg EcoCity. At a much larger scale, Sseesamirembe has received financial backing worth $\$ 1.5$ billion from China, one of the largest Chinese investments in Africa to date. Several European engineering, architecture and research groups (including Arup, MVRDV, Sweco, VTT) are co-developing eco-cities with local partners in China (Changxing, MenTouGou, Tangshan Caofeidian) and South Korea (Gwang Gyo), while South Korean companies have also been involved in several Chinese initiatives (including Tianjin Binhai, Wanzhuang). Within the European Union, Helsingor/Helsingborg (Denmark/Sweden), Trondheim (Norway) and Tudela (Spain) have joined forces to develop and implement urban sustainability measures through the European Commission-funded Eco-City project [10]. 
At political level, international initiatives, such as the C40 Cities Climate Change Leadership Group, the World Economic Forum's SlimCity, the Clinton Climate Initiative, and the Copenhagen Climate Summit for Mayors (2009) - which resulted in the publication of the Copenhagen Climate Сотmипiqué [20] signed by 50 mayors urging national governments to 'acknowledge internationally the pivotal role of cities fighting climate change' - have provided important fora for cross-national knowledge exchange, dialogue and co-operation among political actors.

\section{CONCLUSIONS}

The findings of this study demonstrate the extent to which the eco-city phenomenon has evolved from its earlier, limited and mainly experimental phases to the present stage characterised by growing global proliferation and policy mainstreaming. Within the currently dominant innovation perspective, new forms of partnerships involving national governments, local authorities, research organisations, architecture and engineering firms and private investors have generated a diverse range of eco-city initiatives, from major new eco-city developments to a multitude of 'retro-fit' programmes. As a way of trying to define and analyse eco-cities and demarcating them from 'normal' cities, this study suggest that it may be useful to take into account several key characteristics - such as development type, phase and implementation mode - and dimensions - including the significance of scale, sectoral overlap and policy mainstreaming - rather than attempting to prescribe the phenomenon narrowly.

Considering driving factors, the current crop of eco-city initiatives appear to reflect, and represent a response to, ongoing global climate change (policy) discourses. Driven by the dual necessity to 'decarbonise' cities as key source of greenhouse gas emissions and to grow urban centres to meet socio-economic demands, eco-cities promise an opportunity to stimulate urban development and regeneration through socio-technological innovation, business development and cultural branding. The international dimension - in the form of both co-operation on the ground between local and international partners and international policy and knowledge exchange networks (such as the C40 Cities Group, and the Copenhagen Climate Summit for Mayors) - appears to be an additional key factor driving the present phenomenon.

In trying to gauge the significance of eco-cities, both individually and collectively, future research should consider outcomes by critically evaluating the degree to which the intended aims have been realised and what substantive results (e.g. greenhouse gas emission cuts, renewable energy uptake, public transport use) have been achieved. Several cities can already point to specific achievements, such as $\mathrm{CO}_{2}$ emissions cuts, improved waste management and increased public transport. However, in many cases assessment at this stage is difficult and premature owing to early stage development. Equally important will be a critical assessment of underlying concepts and rationales, and how these correspond to the reality of eco-city practice.

Further research also needs to address the processes of eco-city development and implementation. Here, two perspectives seem particularly relevant: the processes of socio-technological innovation and political and socio-economic governance. Concerning the former, eco-cities may be understood as sites, or 'laboratories', of knowledge creation and transfer, through which new technologies and innovation processes are developed, tested and diffused. As this study shows, various modes and networks of innovation exist: some emphasising particular technologies and/ or policy sectors; others using a more 'blended' approach of integrating different technologies, policy areas, concepts and visions. In addition, some eco-city projects have an explicit remit to foster social learning and education. Thus, future research should inquire into who and what drives these innovation processes, what are enabling and limiting factors, and what outcomes are achieved. 
Considering the aspect of governance, eco-cities are situated in, and are conditioned by, various contexts of social, economic and political governance. This is particularly so in the case of 'retro-fits', where innovation takes place within, and has to engage with, often long-established governance structures and processes, as well as historical and cultural contexts. Here, it will be important to learn from those initiatives - such as Freiburg, Portland, St Davids and Vaxjo - which appear to have effectively harnessed existing governance mechanisms and built on cultural heritage. A 'clean slate' approach, using new developments, may initially seem to be less restricting in terms of having to fit into predetermined governance modes. Interestingly, however, there are several recent examples of new eco-city initiatives - including Dongtan, the English eco-towns, and Logrono Montecorvo - that have faced various, context-specific policy challenges and political controversies. Research, then, should inquire into how eco-cities are politically, economically, socially and culturally governed, what tensions and conflicts may arise between technological innovation, urban development and sustainable living, and how these may be resolved within a framework of democratic governance.

\section{ACKNOWLEDGEMENTS}

This study was supported by a grant from the Nirman Foundation (USA). I am indebted to Robert Kargon, Arthur Molella and Daniel Tomozeiu for their contributions to this research.

\section{REFERENCES}

[1] Joss, S., Eco-cities: a global survey 2009. WIT Transactions on Ecology and the Environment, 129, pp. 239-250, 2010. doi:http://dx.doi.org/10.2495/SC100211

[2] Barton, H., Sustainable Communities: The Potential for Eco-Neighbourhoods, Earthscan Publishers: London, 2000.

[3] Downton, P.F., Ecopolis, Springer: Dordrecht, 2009.

[4] Kargon, R.H. \& Molella A.P., Invented Edens: Techno-Cities of the Twentieth Century, The MIT Press: Cambridge, MA, 2008.

[5] Register, R., Ecocity Berkeley: Building Cities for a Healthy Future, North Atlantic Books: Berkeley, CA, 1987.

[6] Roseland, M., Dimensions of the eco-city. Cities, 14(4), pp. 197-202, 1997. doi:http://dx.doi. org/10.1016/S0264-2751(97)00003-6

[7] Macedo, J., City profile Curitiba. Cities, 21(6), pp. 537-549, 2004.

[8] Laituri, M., Cross-cultural dynamics in the eco-city: Waitakere City, New Zealand. Cities, 13(5), pp. 329-337, 1996. doi:http://dx.doi.org/10.1016/0264-2751(96)00020-0

[9] Mega, V. Cities inventing the civilisation of sustainability: an odyssey in the urban archipelago of the European Union. Cities, 17(3), pp. 227-236, 2000.doi:http://dx.doi.org/10.1016/ S0264-2751(00)00015-9

[10] Clinton Climate Initiative, www.clintonfoundation.org, C40 Cities, www.c40cities.org, EcoCity Project, www.ecocity-project.eu, SlimCity, www.weforum.org.

[11] Barry, J. \& Quilley, S., Transition towns: 'survival', 'resilience' and sustainable communities outline of a research agenda. Ecopolitics Online, 1(2), pp. 12-29, 2009.

[12] Ecocity Builders, www.ecocitybuilders.org

[13] Department for Communities and Local Government, Eco-towns: Living a Greener Future. HMSO: London, April 2008.

[14] Eco-Cities, www.eco-cities.net; Ecocity World Summit www.ecocityworldsummit.org, Sustainable Cities, www.sustainablecities.org.uk

[15] Joss, S., Eco-Cities - A Global Survey 2009. Part A: Eco-City Profiles. University of Westminster: London, May 2010. www.westminster.ac.uk/ecocities 
[16] United Nations. The State of the World's Cities 2006, UN Press: Nairobi, pp. 6-11, 2006.

[17] Wong, J.L., Eco-infrastructure: letting nature do the work. www.greenleapforward.com/2009/ 02/27/eco-infrastructure-letting-nature-do-the-work/

[18] Oneindia, India, Japan to build eco friendly cities in Delhi-Mumbai industrial corridor, 30 April 2010, http://news.oneindia.in/2010/04/30/indiajapan-to-build-eco-friendly-cities-in-delhimu.html

[19] Thames Gateway Institute for Sustainability, www.instituteforsustainability.co.uk

[20] TheCopenhagenClimateCommuniqué.CitiesAct.Copenhagen,2009.http://www.kk.dk/Nyheder/ 2009/December/TheCopenhagenClimateCommunique.aspx 